Article

\title{
Social Capital and Stock Market Participation via Technologies: The Role of Households' Risk Attitude and Cognitive Ability
}

\author{
Ya-Fang Cheng ${ }^{1}$, Eugene Burgos Mutuc ${ }^{2,3}$, Fu-Sheng Tsai ${ }^{1,2, *(\mathbb{D})}$, Kun-Hwa Lu ${ }^{1,4}$ and \\ Chien-Ho Lin ${ }^{1}$ \\ 1 Department of Business Administration, Cheng Shiu University, Kaohsiung 833, Taiwan; \\ 0359@gcloud.csu.edu.tw (Y.-F.C.); lukunhwa1@hotmail.com (K.-H.L.); \\ linchienho1234@outlook.com (C.-H.L.) \\ 2 Postgraduate Program in Management, I-Shou University, Kaohsiung 840, Taiwan; \\ eugene.mutuc@bulsu.edu.ph or eugenemutuc1@yahoo.com \\ 3 Department of Finance, Bulacan State University, Malolos City 3000, Philippines \\ 4 Nan Jehn Natural Gas Co., Ltd., Kaohsiung 833, Taiwan \\ * Correspondence: fusheng_tsai@hotmail.com; Tel.: +886-7-7310606
}

Received: 18 May 2018; Accepted: 5 June 2018; Published: 7 June 2018

\begin{abstract}
This article reviews the relation between social capital and stock market participation via new technology. Its purpose is to acquire a thorough understanding of the structural, relational, and cognitive aspects of social capital's influences and to recommend further empirical research ideas to the existing body of knowledge on household finance. It discusses the consideration of modern and highly technological platforms such as the internet stock market exchange platforms and applications. The stock market participation puzzle remains unsolved despite the progress in explaining the economic rationality behind investors decision making through behavioral finance. Furthermore, the researchers develop four propositions which can expound the existing relationship between social capital dimensions such as the structural, relational, and cognitive aspects and stock market participation of households. Doing so, we discuss the roles of risk attitude and the influence of cognitive ability such as financial awareness, financial literacy, and IQ (intelligence quotient) to enhance the existing body of knowledge. Practically, this article adds valuable ideas in solving the issue of limited participation not just in the stock market but in other financial markets through reflecting on the sociological and (green) technological concepts. Lastly, the implications for sustainable financial markets are elaborated.
\end{abstract}

Keywords: social capital; stock marketing participation; technology; green and sustainability in finance

\section{Introduction}

Gone are the days when traders yell out to each other to match buy and sell orders from the investors. At present, the technology maximizes the time taken to complete a deal and process bulk transactions. Thapar [1] discussed that trading evolution in the stock market had started in the 1960s wherein the order booking process was initiated by calling and asking a broker to enter the order in the system on behalf of the investors. There were different developments in stock trading after this era which include electronic trading in the 80s, online trading in the 90s and high-frequency trading in the year 2000 [1]. Today, social media is integrated into stock trading where live tweets are incorporated by information companies to provide economic data services and monitor the abnormal movements 
of stock prices of specific firms. The research opportunity and stock purchase are made possible by modern technology and high-tech trading.

The development in stock trading is observed as one of the fast-paced needs of the investing community. In line with these changes, investors became more rational in investment participation. The behavior of households has recently been used to explain investment decisions. Household behavior is challenging to study due to the complexity in measurement and constraints not covered in textbook models [2]. In line with this, behavioral finance has become the prime agenda for emerging research fields with an increasing number of arguments for the behavior explanation outside of the traditional boundaries [3]. Moreover, this area is modified to the different assumptions of the rational expectations model through the aspects of behavior and cognitive psychological theory such as sentiment, overconfidence, asymmetric preferences, anchoring, and culture. In effect, there is progress in exploring and explaining the rationality behind investor decision making through behavioral finance [4]. The previous studies on investment decision, particularly in stock market participation, have focused on solving the participation puzzle by linking social factors [5-13].

The participation in stock investment can be made through the primary market and secondary market. The bulk of exchange trading occurs in the secondary market. This is the "stock market" households usually refer to when they talk about stock investment. Stock market participation is the ownership of shares in a company or property, and the purchase of shares through options or by allowing partial ownership in exchange for financing [14]. Giannetti and Wang [15] also defined stock market participation as household ownership of any shares in publicly held corporations, mutual funds, or investment trusts, in each year.

The low stock market participation rates have attracted attention from both academics and policy makers [16-18]. This low participation rate among households becomes a puzzle in which households are reluctant to allocate their money in stock investments despite the fact that stocks have a high mean return [17]. The participation costs and behavioral approaches are the two larger strands of literature in the empirical explanation of the stock market participation puzzle [19]. This conjecture is supported by several proposed explanations in the literature contemplating the role of participation costs in solving this puzzle $[17,20-26]$. Moreover, scholars also reflected on behavioral approaches such as risk attitude [15,27-33]; cognitive ability of households such as financial awareness [34], financial literacy [35], and IQ [36]; and sociological aspects including social interaction [5,8,12], trust [7,11] and shared vision $[6,9,10,13]$. This study reflects on the articles, considering risk attitude, cognitive ability, and sociological factors to explain the puzzle in stock market participation from the recommended journals in finance such as the Journal of Finance, Journal of Financial Economics, Review of Financial Studies, and Review of Finance.

These past literatures have enriched our knowledge and understanding towards the stock market participation puzzle among households. However, social capital and its dimension remain unexplored in explaining the participation puzzle. This paper argues that social capital dimensions such as structural, relational, and cognitive aspects can make a clear understanding of the participation puzzle if analyzed properly [37]. Nahapiet and Ghoshal [37] explained that the social capital theory suggests that value creation is possible from the facilitated action caused by the permitted access to resources from social relationships. This paper also discusses the consideration of modern platforms such as the internet in stock market participation from new and old household investors due to its continuous development and rapid growth. Bogan [38] contended that many areas within the economic and finance literature discuss the potential of the internet to affect every aspect of daily life. To bridge the emerging gap in the existing literature of investment participation in behavioral finance, this study aims to develop a framework and formulate propositions to enhance scholarly conversation on how to address the stock market participation puzzle. Our research question is: How do social capital and its dimensions influence stock market participation among households? Our paper aims to reveal the importance of social capital and increase its recognition in explaining topics in behavioral finance such as stock market participation. 
Therefore, this conceptual paper sets to make contribution through the developed propositions to literature on household and behavioral finance and further enhance the existing relationship of the sociological variables used in explaining stock market participation. In nature, a conceptual paper is basically grounded on theoretical arguments, theories, frameworks, etc. Such papers are also of an important form as a scientific publication and tend not to use empirical data. Also because of the nature, a conceptual paper normally has no intentions to run statistical analytical procedures, and should follow the structural and logical form of what is normally accepted by the scientific community. We structure this paper as follow. First is the aggregate and independent role of social capital dimensions to stock market participation of households. Second is the inferring role of risk attitude to the relation of structural social capital on stock market participation. Third is the mediating role of risk attitude to the relation of relational social capital on stock market participation. Lastly, the role of cognitive ability of households such as financial awareness, financial literacy and IQ in the relationship between cognitive social capital and stock market participation.

The rest of the paper is organized as follows: Section 2 reviews the relevant literature, Section 3 presents the overall discussion, and Section 4 concludes the paper and recommends further studies.

\section{Literature Review}

This section discusses the literature in stock market participation, social capital and related studies about social capital relation on stock market participation.

\subsection{Stock Market Participation}

The household behavior is challenging to study due to the complexity in measurement and constraints not covered in the textbook models [2]. Significant mistakes in investment decisions are commonly committed by poor and less educated households than rich and well-educated investors. Human capital is an important nontraded asset of households used in planning over a long and certain period of time. The complexity in the financial planning problem and the often-confusing financial products offered to households are the common reasons for these committed mistakes [2]. This clarification leads to the issue of determining the set of financial products available to households. However, Brown et al. [6] argued that households can still make serious investment mistakes even though many households find adequate solutions to the complex investment problems they face such as non-participation in risky asset markets, under-diversification of risky portfolios, and failure to exercise options to refinance mortgages.

Households will be benefited if the sources of these usually committed mistakes will be identified and explained properly. The participation of a household in investing activities is essential in computing the Gross Domestic Product (GDP) of a country to measure the market value of all the final goods and services produced at a given period. The principle of time value of money in finance explains the importance of investment, that the value of money today is not its value tomorrow. The stock market is one of the channels where households can participate in investing activities. The limited participation of households in the stock market postulates a significant challenge to financial theory and a consistent fact in household finance. Many scholars such as Mankiw and Zeldes [16], Haliassos and Bertaut [17], and Heaton and Lucas [22] conjectured that even among affluent households, the participation in investment activities is also limited.

The participation costs and behavioral approaches are the two larger strands of literature in the empirical explanation of stock market participation [19]. This conjecture is supported by several proposed explanations in the literature contemplating the role of participation costs in the stock market participation puzzle. During the early years, scholars reflected on the cost of information upon entry in the equity market. Allen and Gale [20] investigated the effects of the interaction of limited market participation and liquidity preference on asset-price volatility and explained that for a range of entry costs, there exists a full participation equilibrium and a limited participation equilibrium. Households initially devote resources to learn the basic features of the market for active 
participation [21]. The inertial costly information such as the process of investing in stocks, institutional developments, financial market trends, and comparative performance of professional advisors can explain why so few hold stocks [17]. These transaction costs usually result in individual consumption which leads to a direct effect on individual income [22]. The cost of participating in the stock market is also an attribute to endogenous fluctuations of market participation which lead to increased volatility of the share price [23].

Eventually, the entry costs in stock market investment became fixed and independent to household investors. Yaron and Zhang [24] discovered that fixed costs such as commission charged by brokers in stock investment may generate low participation patterns. A relatively small fixed cost for stock market participation can induce household stockholding [25]. Households are trying to be rational but the information to be so is expensive [26]. Moreover, agents with relatively low labor income at large fixed cost of trading equities will choose not to participate in the equity market [39] and agents who are financially able to pay the cost have access to a larger investment opportunity [30]. Bogan [38] examined the relation between the decline in transaction costs due to the availability of online stock trading and stock information, and the implications for the stock market participation puzzle. Many major U.S. financial service firms have developed a sizeable online customer base while other companies have focused on providing online stock information and financial analysis tools since the online trading trend emerged in the 1990s [1].

Personal and family background of households are also considered to address the issue of limited participation in the stock market. The socio-economic status of households may affect stock market participation. Households with lower socio-economic status form more pessimistic beliefs about the distribution of stock returns and are less likely to invest in stocks [40]. In addition, change in educational status affects the likelihood of holding stocks and individuals who studied economics are more likely to hold stocks than otherwise identical investors [41]. Genetic factors are also considered in assimilating stock market participation. These factors explain about one-third of the variance in stock market participation and asset allocation [42]. Cronqvist et al. [43] incorporated the fetal origins hypothesis into finance research and discovered that the differences in an individual's prenatal environment explain the heterogeneity in financial risk-taking propensities much later in life.

Other scholars reflect on the wealth and income of households to explain stock market participation. An increase in institutionalized savings does not necessarily lead to more dispersed ownership and market-oriented financial systems [44]. Outstanding debt is also considered since it affects the wealth and income of households. The equity market participation can be traded off by households to pay the high interest payment on their debt [45]. However, any unexpected huge amount of money received by households or windfall wealth may have a positive effect on stock participation [46]. Taxation policy also contributes to the influence of wealth and income in the participation puzzle. Fischer and Jensen [19] studied the impact of a redistributive tax system on consumption, portfolio decisions, and asset prices in a dynamic general equilibrium model and conjectured that poorer agents, which receive more in transfers than they pay in taxes, optimally reduce their exposure to equity, because the transfer income they receive is subject to stock market risk.

\subsection{Social Capital}

Social capital is the new picture to characterize the investment decisions of households. Coleman [47] explained that it consists of some aspect of social structure and it enables a particular activity of individuals who are within the structure. Furthermore, Portes and Sensenbrenner [48] identified social capital as the propensity of an individual to be included in a social network or other social means accentuating social capital's function in a variety of parameters.

Social capital has three distinctive but interrelated dimensions. First is the structural social capital in which social interaction is evident to the individual with a desired set of knowledge. Second is the cognitive social capital in which shared visions are acquired within a created and sustained relationship. Lastly, the relational social capital in which normative factors are the underlying guide in 
the exchange relationship, such as trust and trustworthiness [37]. These three social capital dimensions with proper coordination of combination and exchange will result in value creation $[37,49]$. However, Edelman et al. [50] argued that a balanced perspective is needed to fully understand the outcome of using social capital since it is an insufficient condition for value creation in organizations.

The above-mentioned dimensions of social capital have been used in understanding the investing and purchasing decisions. Hong et al. [5] wrote a seminal paper and explained stock market participation using structural social capital and studied social interaction. The role of sociability was studied by Georgarakos and Pasini [8], while Campbell et al. [12] reflected on the influence of social engagement on stock market participation. Other scholars reflect on the relational aspect of social capital. For instance, Guiso et al. [7], Georgarakos and Pasini [8], and Balloch et al. [11] considered trust to explain the limited participation while Georgarakos and Inderst [51] studied the impact of trust to professional financial advice to explain stock market participation. Brown et al. [52] made a seminal study about cognitive social capital and reflected on the investment behavior of members of the community to explain stock market participation. Another study used community participation to explain the phenomenon [6]. Kaustia and Knüpfer [9] analyze peer performance while the co-worker's investment decision is considered in the study of Hvide and Östberg [10] to explain stock market participation.

\subsection{Social Capital Dimensions and Stock Market Participation}

The three distinctive but interrelated dimensions of social capital一 the structural, relational (trust), and cognitive (shared vision) aspects [37] —are examined by other scholars to fill the gap in stock market participation among households. A seminal study on structural social capital considering social interaction was conducted and it was revealed that social households, or those who interact with their neighbors or attend church, are substantially more likely to invest in the market than non-social households and concluded that the impact of sociability is stronger in states where stockmarket participation rates are higher [5]. In addition, Georgarakos and Pasini [8] discussed that sociability can equalize the impact of despondency on stock market participation instigated by low existing trust within places. Moreover, socially engaged individuals are more likely to participate in stock investment [12].

Doney and Cannon [53] wrote a paper about the nature of trust in buyer-seller relationships and conjecture that the trust of the supplier firm and the salesperson with their indirect operation through supplier firm trust affects buyers' anticipated future interaction with the supplier after controlling for delivery performance, relative cost, product or service performance, and purchase experience with the supplier. This buyer and seller relationship is also applicable to decision making of households in the stock market. A less trusting individual is less likely to buy stock; a lack of trust of households in the stock market is an important factor in explaining the limited participation puzzle [7]. Trust has a strong relevant impact on places with low participation in the stock market, which explains the limited stockholdings of wealthy households therein [8]. Financial advice is also examined to discern the role of trust in relational social capital to explain stock market participation. Households' trust in financial advice only matters when their perceived own financial capability is low and households with higher financial capability reflect on the perception of legal protection in financial markets to participate in the stock market [51]. Moreover, economic shocks and future expectations are key behavioral characteristics that explain a household's decision to invest in stocks and trust explains not only the probability of participation but also the conditional factor on participation [11].

The shared vision of a community, group, and peers to discuss the role of cognitive social capital is also investigated in the body of literature explaining the participation puzzle. This is in line with the study of Childers and Rao [54] about peer groups' suggestion in choosing and deciding what products or brands to purchase and conjecture that the influence of the reference-group may vary depending on whether the suggestion is exercised by a member of a peer group or by a family member. Individuals are influenced by the investment behavior of members of their community and households 
prefer to live near people who are like them [52]. In addition, there is a strong result of stock market participation in the more sociable communities where word-of-mouth communication is established [6]. The local peers experience in stock returns also affect an individual's stock market entry decision, particularly in areas with better opportunities for social learning [9]. However, the coworkers' activity in the stock market cannot influence the improvement of the quality of investment decisions of an individual [10]. Recently, KnÜPfer et al. [13] traced the impact of formative experiences on portfolio choice and conjectured that individuals whose neighbors and family members experienced adverse circumstances also avoid risky investments.

Social interaction, trust, and shared visions such as observable learning, community participation, peer's experience, and coworker's investment performance are the factors considered from previous studies. These factors are in accordance to the social capital dimensions namely: the structural, relational, and cognitive aspects. These previous studies consider a direct causal relationship to explain the phenomenon in stock market participation. Although there is an existing relationship between the social capital dimension and stock market participation, the puzzle of limited participation remained as a fact of issues in investing decisions of households. This paper reflects on the idea that the relationship between social capital dimensions and stock market participation after controlling different direct variables can be enhanced further for a better understanding of the phenomenon and make a contribution to the existing body of knowledge on household finance. It will also contemplate the role of social capital dimensions in the access of online information of households to participate in the stock market. This conjecture is parallel to the study of Bogan [38] regarding the role of the internet in stock market participation. He discovered that there is a fundamental change in participation and links this change to the reduction of these frictions by the advent of the internet. Moreover, this study provides propositions to challenge the existing effect of social capital dimensions on stock market participation.

The first proposition of this study is the combination of the three social capital dimensions to explain the investment participation of households in stock markets. These dimensions are distinctive but interrelated [37]. This study proposes the examination of these three dimensions and controls each other to show the significant effect on stock market participation. This notion is the idea that if the structural, relational, and cognitive dimension will be combined, it may have a strong significant effect on the explanation of stock market participation. Social interaction and shared vision are both reflecting on the social engagements while trust as a relational dimension of social capital considers personal values.

Secondly, consideration of the risk attitude may infer the existing relationship between the structural social capital and stock market participation. The studies of Cao et al. [28], Kumar [55], Gormley et al. [31], Kumar et al. [29], Bonaparte et al. [33], and Giannetti and Wang [15] established a clear influence of risk attitude in explaining stock market participation. This factor can give a clear understanding of the relationship between social interaction and the investment participation by identifying the risk aversion and risk taking of households. This is an interesting topic because there is a possibility that risk averse but socially engaged household may participate in stock investment, or a risk taker but not socially engaged household may participate in stock investment.

Third, the consideration of risk attitude since it is a variable that is caused by trust which can directly impact the stock market participation of households. This concept proposes that risk attitude affects the relational dimension of social capital (trust) which has an existing, direct causal relationship to stock market participation. This notion is motivated from the previous studies about risk aversion [27], uncertainty dispersion [28], and loss aversion [32]. Moreover, Michaelides and Haliassos [25] and Gomes and Michaelides [30] are also considered in this conjecture regarding the accumulation of wealth of households with a risk-averse attitude.

Lastly, the moderating role of cognitive ability of households such as financial literacy, financial awareness, and the intelligence quotient are factors that scholars may look upon to establish a clear relationship between the cognitive aspect of social capital and stock market participation. 
Grinblatt et al. [36] conjectured that households with high IQ have a high possibility to participate in mutual fund investment and huge numbers of stocks. The study of Van Rooij et al. [35] revealed that households with low financial literacy are much less likely to invest in stocks. Guiso and Jappelli [34] explained that financial awareness and cost estimation of households influences consequential involvement in the stock market. This notion proposes that a non-participating household in a group with a shared vison and high cognitive ability may participate in the stock market, or participating households in a group with a shared vison and low cognitive ability may participate in the stock market.

\section{Discussions and Arguments}

The impact of participation costs and other fixed entry costs are no longer discussed from previous studies since these costs are certain in stock market investment. Most scholars discuss social capital dimensions to explain stock market participation such as social interaction with peers, sociability to balance trust issues, and social engagement for structural aspects. Other studies reflect on the relational social capital dimension such as trust, economic shocks and future expectations. Moreover, scholars have also contemplated the cognitive aspects of social capital such as established word-of-mouth communication in a sociable community, adoption of financial innovations and investment styles of peer performance, co-workers' interaction in investment choices, and formative experiences relating to other areas of life.

Risk attitude is also considered to explain stock market participation such as uncertainty dispersion, an individual's propensity to gamble, existence of a large and negative wealth shock, religion-induced gambling attitudes, revelation of corporate fraud in the society, and high hedging potential. Other scholars discussed cognitive ability to explain stock market participation such as the implications of financial awareness, high financial literacy, particularly basic financial knowledge, personal values of left-wing voters and politicians, intelligence quotient of an individual and an increase of wealth inequality.

Wealth and income are also considered to discern the phenomenon in stock market participation, such as the acquisition of public pension funds, household debt, exogenous variation in financial wealth, and government policy in taxation. Other scholars also had an explicit discussion about stock market participation and considered personal and family background such as changes in the educational status of an individual, genetic component of decision making, prenatal environment, and individuals with higher socioeconomic status.

The social capital dimensions- the structural (social interaction), relational (trust), and cognitive (shared vision) aspects-are increasingly recognized in explaining stock market participation and are an emerging research issue in behavioral finance studies. Risk attitude and cognitive ability such as IQ, financial awareness, and financial literacy of households are also relevant factors to assimilate the phenomenon. The role of peers, community and trust in household investment decision making are also conspicuous and the variation to the social capital dimensions occurred before the variation in stock market participation. The review of past literature discussing social capital dimensions and its effect on stock investment participation reveals the importance of scrutinizing household behavior in terms of an interpersonal approach in solving the limited stock market participation for economic welfare, financial markets, and an individual's expected lifetime income and consumption.

The researcher believes that the rapid growth and development in internet technology provides changes in the methods of households' stock market participation. Technology in the form of internet alleviated the three common reasons why there is a stock market participation puzzle: transaction costs, information costs, and limited access (Bogan, 2008). This paper will reflect on the role of social capital dimensions in the access of information of households in stock market participation. This paper develops four propositions, considering the stock market participation of households through a new, highly technological platform, for a better understanding of the phenomenon. These propositions aim to make a contribution to the existing body of knowledge on household finance. This study also presents a conceptual framework for each proposition. 
The first proposition is the examination of the three dimensions of social capital to show the significant effect on stock market participation. This main proposition is divided into two sub-propositions about this concept-Figure 1a,b.

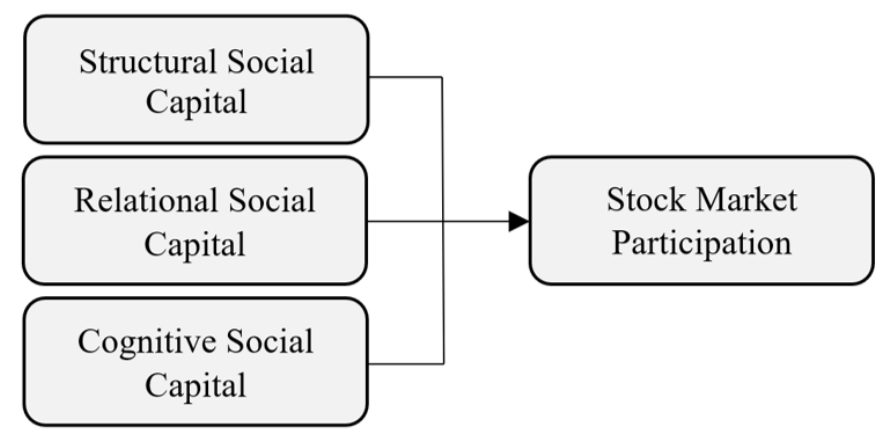

(a)

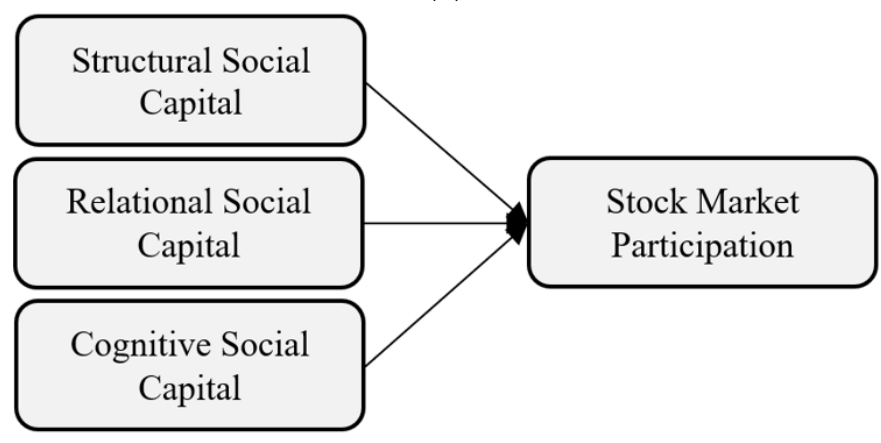

(b)

Figure 1. (a) Schematic Diagram of Conceptual Model of the Aggregate Social Capital Dimensions and Stock Market Participation. (b) Schematic Diagram of Conceptual Model of the Independent Social Capital Dimensions and Stock Market Participation.

At first, the social capital dimensions, the structural, relational, and cognitive aspect, will give an aggregate explanation on stock market participation. This proposition suggests that an active household on highly technological platforms and other related websites may participate in the stock market since interaction and learnings are easier online. Social capital is a multidimensional construct that exists at the same level as its dimension and can be combined to form an overall representation of the social capital.

Second, the independent role of these dimensions in explaining stock market participation. This proposition is motivated by the explanation that these dimensions are distinctive but interrelated [37]. This proposition suggests that an active household on highly technological platforms and other related websites may participate in the stock market. This notion considers issues in online social interaction, trust in online community, and shared visions within online investors. This idea is another essential proposition since social capital is an emerging research topic to explain the behavioral finance and can make contributions to the existing body of knowledge on household finance. This conjecture is also motivated from the studies of Hong et al. [5], Georgarakos and Pasini [8], and Campbell et al. [12] about structural social capital, Guiso et al. [7], Georgarakos and Inderst [51], and Balloch et al. [11] about relational social capital, and Brown et al. [6], Kaustia and Knüpfer [9], Hvide and Östberg [10], and KnÜPfer et al. [13] about cognitive social capital to explain stock market participation.

Figure 2 shows the second proposition of this study considering risk attitude to infer the existing relationship between the structural social capital and stock market participation. This notion proposes that risk-averse but socially engaged households in highly technological platforms may participate in stock investment or a risk taker but not socially engaged household in highly technological platforms 
may participate in stock investment. There are scholars contemplating the structural dimensions of social capital to explain the phenomenon of limited participation. Hong et al. [5] wrote a seminal paper and explained stock market participation using structural social capital and studied social interaction. Moreover, Georgarakos and Pasini [8] studied sociability while Campbell et al. [12] studied the influence of social engagement on stock market participation. This proposition considers the risk attitude of households such as risk aversion and risk taking. The moderating role of risk attitude will be tested to show its inference on the existing relationships of structural social capital and stock market participation. This proposition can provide a new interpretation on the boundary condition of existing knowledge since risk is one of the conditional factors considered by households. This conjecture is motivated by the conclusion of the study of Barsky et al. [27] that people's risk-taking propensity in one setting predicts risky behavior in other settings.

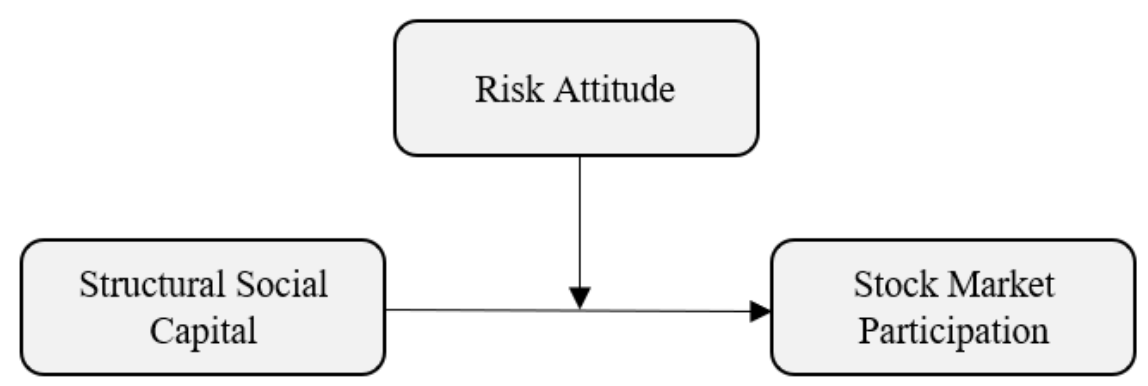

Figure 2. Schematic Diagram of Conceptual Model of Structural Social Capital and Stock Market Participation.

As the Figure 3 showed, the third proposition is the consideration of risk attitude, since it is a variable that is caused by trust which can directly impact the stock market participation of households. This concept proposes that risk attitude affects the relational dimension of social capital (trust) which has an existing direct-causal relationship to stock market participation. There are different issues regarding trust in investment activities and reflecting on a highly technological platform may give rise to the matter in questions regarding stock market participation of households. For instance, Guiso et al. [7], Georgarakos and Pasini [8], and Balloch et al. [11] considered trust to explain the limited participation while Georgarakos and Inderst [51] studied the impact of trust on professional financial advice to explain stock market participation. Kumar et al. [29] considered the risk attitude and the role of trust in investment decision while Giannetti and Wang [15] provided evidence that the risk attitude on household stock market participation is due to a loss of trust in the stock market. This notion is also motivated from the previous studies about risk aversion [27], uncertainty dispersion [28], and loss aversion [32]. Moreover, Michaelides and Haliassos [23] and Gomes and Michaelides [30] are also considered in this conjecture regarding the accumulation of wealth of households with a risk-averse attitude.

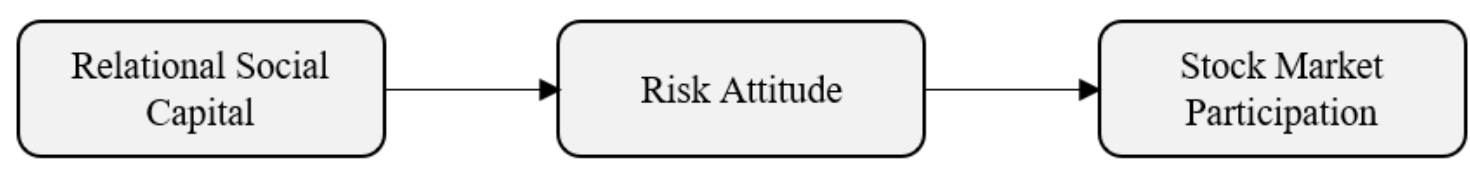

Figure 3. Schematic Diagram of Conceptual Model of Relational Social Capital and Stock Market Participation.

Figure 4 shows the moderating role of cognitive ability of households that scholars may look upon to establish a clear relationship between the cognitive aspect of social capital and stock market participation. Many major U.S. financial service firms have developed a sizeable online customer platform since the online trading trend emerged in the 1990s [38]. In line with this, many online 
communities arise, sharing ideas and offering learning platforms. Brown et al. [6] made a seminal study about cognitive social capital and reflected on community participation to explain stock market participation. Kaustia and Knüpfer [9] analyzed peer performance while the co-worker's investment decision is considered in the study of Hvide and Östberg [10] to explain stock market participation. KnÜPfer et al. [13] traced the impact of formative experiences of neighbors and family members to explain the phenomenon. The previous studies about shared visions are in line with the study of Childers and Rao [54] that the influence of a reference group may vary depending on whether the suggestion is exercised by a member of a peer group or by a family member.

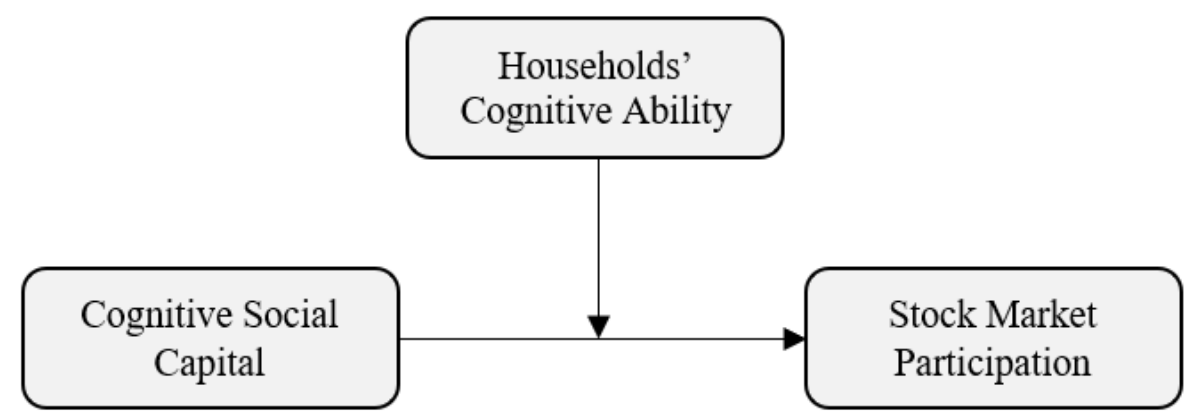

Figure 4. Schematic Diagram of Conceptual Model of Cognitive Social Capital and Stock Market Participation.

This notion proposes that a non-participating household in a group with a shared vison and high level of IQ may participate in the stock market or participating households in a group with a shared vison and low level of IQ may participate in stock market. Another concept scholars may look at is the notion that a non-participating household in a group with a shared vison and high level of financial literacy may participate in the stock market or participating households in a group with a shared vison and low level of financial literacy may participate in the stock market. Scholars may also reflect on the notion that a non-participating household in a group with a shared vison and a high level of financial awareness may participate in the stock market or participating households in a group with a shared vison and low level of financial awareness may participate in stock market. This conjecture is motivated by the notion that households with a high level of IQ, financially literate and financially aware will participate in the stock market $[6,9,10]$.

\section{Conclusions and Future Research}

This study is a review of articles reflecting on the relationship between social capital dimensions and stock market participation. This is done to acquire a thorough understanding of the application of structural, relational, and cognitive aspects to describe the phenomenon and to recommend further empirical research ideas in contribution to the existing body of knowledge on household finance. It discusses the consideration of modern and highly technological platforms such as the internet in stock market participation of new and old household investors. It reflects on the significant technological advancement of the last century and the continuous development and rapid growth of the internet, since many areas within economic literature discuss its potential, which affects every aspect of a households daily living.

If household finance can achieve a thorough understanding of stock market participation considering social capital dimensions in a highly technological platform such as electronic trading, online trading, algorithms and low latency, it may be possible to contribute and generate ideas in solving the participation puzzle over risky investments. The social capital dimensions-the structural (social interaction), relational (trust), and cognitive (shared vision) aspects—are increasingly recognized in explaining stock market participation. Risk attitude and cognitive ability such as IQ, financial awareness, and financial literacy of households are also relevant factors to assimilate the 
phenomenon. The impact of participation costs and other fixed entry costs are no longer discussed in recent studies since these costs are certain in stock market investment. However, Bogan (2008) examined the effect of the internet on transaction costs in stock market participation and contended that computer/internet-using households raised participation substantially more than non-computer-using households, since these costs lessen due to the utilization of the new platform. Moreover, the researcher conjectures that highly technological platforms are not only relevant to lessen market entry costs but are a new channel to examine its role in social capital and reflect on the investment mistakes of households. These mistakes may lead to huge participation costs if not avoided or managed properly by households [2]. This study also conjectures that reflecting on these sociological aspects in explaining stock market participation may eliminate household mistakes in investment and maximize the participation costs to revitalize the spirit of financial engineering in the retail marketplace.

This study contributes to emerging research about behavioral finance by employing the sociological aspect in explaining finance issues. Household investment decisions such as household participation in the equity market can be linked to consumer buying decision wherein social capital dimensions are antecedent factors in interpreting the phenomenon. Apparently, the variation to the social capital dimensions occurred before the variation in stock market participation. This study presents propositions to enhance the existing relationship discussed from the previous studies about stock investment decisions. The application of these propositions to future research activity may enrich the prevailing knowledge in household finance.

The main proposition of this study is the examination of social capital dimensions such as the structural, relational, and cognitive aspects, which give an aggregate explanation on stock market participation since social capital is a multidimensional construct but the independent role of each dimensions are distinctive but interrelated in explaining stock market participation. This proposition suggests that an active household on a highly technological platform and other related websites may participate in the stock market since interaction and learnings are easier online. This notion considers issues in online social interaction, trust in online community, and shared visions within online investors. The risk attitude of households is also considered in developing propositions to enhance the existing relationship between social capital dimensions and stock market participation. This paper proposes that risk-averse but socially-engaged households on highly technological platforms may participate in stock investment or a risk taker but not socially engaged household on highly technological platforms may participate in stock investment. Risk attitude is a variable caused by trust which can directly impact the stock market participation of households. In line with this, this paper proposes that risk attitude affects the relational dimension of social capital (trust) which has an existing direct causal relationship to stock market participation. There are different issues regarding trust in investment activities and reflecting on the highly technological platform may give rise to questions regarding stock market participation of households. Lastly, this paper proposes the consideration of the moderating role of cognitive ability of households such as financial literacy, financial awareness, and IQ level to draw a conclusive understanding of stock market participation since many online communities arise sharing ideas and offering learning platforms.

Moreover, households were treated as unitary entities in the recent studies about stock market participation, not taking into consideration the possibility of haggling among family members which influence household decisions. Households, as respondents of the selected articles regarding stock market participation, can explain the participation puzzle in the equity market; however, considering different ages, professions, educational backgrounds, etc., may also give a clear picture of the stock market participation puzzle. Each member of a household has different preferences and knowledge towards highly technological platforms. This study suggests a more specific definition of stock market participation depending on the level of participation. In line with this, the researcher also recommends that future research reflect upon the available types of financial products and to classify them with direct and indirect participation of households in stock investment. This notion is motivated by the conjecture of Campbell [2] that households commit mistakes because of the often-confusing financial 
products that are offered to them and the increasing role of financial advisors, due to the complexity of the financial products offered to them [51].

The stock market is a risky investment. It is always supported by the risk and return trade-off. It is very inspiring that household finance may be able to improve the welfare of households [2] and learning the role of highly technological platforms in social capital dimensions may give an explanation to the participation puzzle in stock market investment. It is risky but proper financial knowledge and social interactions may lead households to successful and profitable participation in the stock market. Warren Buffet has always mentioned and advised to never invest in a business you cannot understand. This study encourages researchers to continuously find valuable ideas in solving the issue of limited participation, not just in stock markets but in other financial markets, through reflecting on the sociological concept in explaining financial issues.

Last but not least, complementary to a conceptual paper like this present one, empirical studies are of equal importance [56,57]. Thus, we encourage future research to design and implement an empirical model that validates the main propositions in this article.

Author Contributions: All authors participated in the idea generation stage. Y.-F.C. wrote up the Introduction section; E.B.M. wrote up the Literature Review and Core Arguments sections; F.-S.T. was in charge of and wrote for the whole R\&R process; K.-H.L. and C.-H.L. finished the Conclusion section.

Acknowledgments: This paper is partially supported by the research project of the Ministry of Science and Technology (MOST) (Project number: MOST-106-2410-H-230-002-).

Conflicts of Interest: The authors declare no conflict of interest.

\section{References}

1. Thapar, N. The Evolution of Trading: Barter System to Algo Trading, Pioneer Institute in Algo Trading. 2017. Available online: https://www.quantinsti.com/blog/evolution-trading-barter-system-algo-trading/ (accessed on 5 June 2018).

2. Campbell, J.Y. Household finance. J. Financ. 2006, 61, 1553-1604. [CrossRef]

3. Linnenluecke, M.K.; Chen, X.; Ling, X.; Smith, T.; Zhu, Y. Research in finance: A review of influential publications and a research agenda. Pac. Basin Financ. J. 2017, 43, 188-199. [CrossRef]

4. Conlin, A.; Kyröläinen, P.; Kaakinen, M.; Järvelin, M.R.; Perttunen, J.; Svento, R. Personality traits and stock market participation. J. Empir. Financ. 2015, 33, 34-50. [CrossRef]

5. Hong, H.; Kubik, J.D.; Stein, J.C. Social interaction and stock-market participation. J. Financ. 2004, 59, 137-163. [CrossRef]

6. Brown, J.R.; Ivković, Z.; Smith, P.A.; Weisbenner, S. Neighbors matter: Causal community effects and stock market participation. J. Financ. 2008, 63, 1509-1531. [CrossRef]

7. Guiso, L.; Sapienza, P.; Zingales, L. Trusting the stock market. J. Financ. 2008, 63, 2557-2600. [CrossRef]

8. Georgarakos, D.; Pasini, G. Trust, sociability, and stock market participation. Rev. Financ. 2011, 15, 693-725. [CrossRef]

9. Kaustia, M.; Knüpfer, S. Peer performance and stock market entry. J. Financ. Econ. 2012, 104, 321-338. [CrossRef]

10. Hvide, H.K.; Östberg, P. Social interaction at work. J. Financ. Econ. 2015, 117, 628-652. [CrossRef]

11. Balloch, A.; Nicolae, A.; Philip, D. Stock market literacy, trust, and participation. Rev. Financ. 2014, 19, 1925-1963. [CrossRef]

12. Changwony, F.K.; Campbell, K.; Tabner, I.T. Social engagement and stock market participation. Rev. Financ. 2014, 19, 317-366. [CrossRef]

13. Knüpfer, S.; Rantapuska, E.; Sarvimäki, M. Formative experiences and portfolio choice: Evidence from the Finnish great depression. J. Financ. 2017, 72, 133-166. [CrossRef]

14. International Working Group on External Debt Statistics. External Debt: Definition, Statistical Coverage and Methodology; International Monetary Fund: Washington, DC, USA, 1988.

15. Giannetti, M.; Wang, T.Y. Corporate scandals and household stock market participation. J. Financ. 2016, 71, 2591-2636. [CrossRef] 
16. Mankiw, N.G.; Zeldes, S.P. The Consumption of Stockholders and Non-stockholders. J. Fin. Econ. 1991, 29, 97-112. [CrossRef]

17. Haliassos, M.; Bertaut, C.C. Why do so few hold stocks? Econ. J. 1995, 105, 1110-1129. [CrossRef]

18. Guiso, L.; Haliassos, M.; Jappelli, T. Household stockholding in Europe: Where do we stand and where do we go? Econ. Policy 2003, 18, 123-170. [CrossRef]

19. Fischer, M.; Jensen, B.A. Taxation, transfer income and stock market participation. Rev. Financ. 2014, 19, 823-863. [CrossRef]

20. Allen, F.; Gale, D. Limited market participation and volatility of asset prices. Am. Econ. Rev. 1994, 84, 933-955.

21. Williamson, S.D. Liquidity and market participation. J. Econ. Dyn. Control 1994, 18, 629-670. [CrossRef]

22. Heaton, J.; Lucas, D.J. Evaluating the effects of incomplete markets on risk sharing and asset pricing. J. Political Econ. 1996, 104, 443-487. [CrossRef]

23. Orosel, G.O. Participation costs, trend chasing, and volatility of stock prices. Rev. Financ. Stud. 1998, 11,521-557. [CrossRef]

24. Yaron, A.; Zhang, H.H. Fixed costs and asset market participation. Rev. Anal. Econ. 2000, 15, 89-109.

25. Haliassos, M.; Michaelides, A. Portfolio choice and liquidity constraints. Int. Econ. Rev. 2003, 44, $143-177$. [CrossRef]

26. Vissing-Jorgensen, A. Perspectives on behavioral finance: Does "irrationality" disappear with wealth? Evidence from expectations and actions. NBER Macroecon. Annu. 2003, 18, 139-194. [CrossRef]

27. Barsky, R.B.; Juster, F.T.; Kimball, M.S.; Shapiro, M.D. Preference parameters and behavioral heterogeneity: An experimental approach in the health and retirement study. Q. J. Econ. 1997, 112, 537-579. [CrossRef]

28. Cao, H.H.; Wang, T.; Zhang, H.H. Model uncertainty, limited market participation, and asset prices. Rev. Financ. Stud. 2005, 18, 1219-1251. [CrossRef]

29. Kumar, A.; Page, J.K.; Spalt, O.G. Religious beliefs, gambling attitudes, and financial market outcomes. J. Financ. Econ. 2011, 102, 671-708. [CrossRef]

30. Gomes, F.; Michaelides, A. Asset pricing with limited risk sharing and heterogeneous agents. Rev. Financ. Stud. 2007, 21, 415-448. [CrossRef]

31. Gormley, T.; Liu, H.; Zhou, G. Limited participation and consumption-saving puzzles: A simple explanation and the role of insurance. J. Financ. Econ. 2010, 96, 331-344. [CrossRef]

32. Dimmock, S.G.; Kouwenberg, R. Loss-aversion and household portfolio choice. J. Empir. Financ. 2010, 17, 441-459. [CrossRef]

33. Bonaparte, Y.; Korniotis, G.M.; Kumar, A. Income hedging and portfolio decisions. J. Financ. Econ. 2014, 113, 300-324. [CrossRef]

34. Guiso, L.; Jappelli, T. Awareness and stock market participation. Rev. Financ. 2005, 9, 537-567. [CrossRef]

35. Van Rooij, M.; Lusardi, A.; Alessie, R. Financial literacy and stock market participation. J. Financ. Econ. 2011, 101, 449-472. [CrossRef]

36. Grinblatt, M.; Keloharju, M.; Linnainmaa, J. IQ and stock market participation. J. Financ. 2011, 66, 2121-2164. [CrossRef]

37. Nahapiet, J.; Ghoshal, S. Social capital, intellectual capital, and the organizational advantage. In Knowledge and Social Capital; Butterworth-Heinemann: Woburn, MA, USA, 2000; pp. 119-157.

38. Bogan, V. Stock market participation and the internet. J. Financ. Quant. Anal. 2008, 43, 191-211. [CrossRef]

39. Polkovnichenko, V. Limited stock market participation and the equity premium. Financ. Res. Lett. 2004, 1, 24-34. [CrossRef]

40. Kuhnen, C.M.; Miu, A.C. Socioeconomic status and learning from financial information. J. Financ. Econ. 2017, 124, 349-372. [CrossRef]

41. Christiansen, C.; Joensen, J.S.; Rangvid, J. Are economists more likely to hold stocks? Rev. Financ. 2007, 12, 465-496. [CrossRef]

42. Barnea, A.; Cronqvist, H.; Siegel, S. Nature or nurture: What determines investor behavior? J. Financ. Econ. 2010, 98, 583-604. [CrossRef]

43. Cronqvist, H.; Previtero, A.; Siegel, S.; White, R.E. The fetal origins hypothesis in finance: Prenatal environment, the gender gap, and investor behavior. Rev. Financ. Stud. 2015, 29, 739-786. [CrossRef]

44. Giannetti, M.; Laeven, L. Pension reform, ownership structure, and corporate governance: Evidence from a natural experiment. Rev. Financ. Stud. 2008, 22, 4091-4127. [CrossRef] 
45. Becker, T.A.; Shabani, R. Outstanding debt and the household portfolio. Rev. Financ. Stud. 2010, 23, $2900-2934$. [CrossRef]

46. Andersen, S.; Nielsen, K.M. Participation constraints in the stock market: Evidence from unexpected inheritance due to sudden death. Rev. Financ. Stud. 2010, 24, 1667-1697. [CrossRef]

47. Coleman, J.S. Social capital in the creation of human capital. In Knowledge and Social Capital; Butterworth-Heinemann: Woburn, MA, USA, 2000; pp. 17-41.

48. Portes, A.; Sensenbrenner, J. Embeddedness and immigration: Notes on the social determinants of economic action. Am. J. Sociol. 1993, 98, 1320-1350. [CrossRef]

49. Tsai, W.; Ghoshal, S. Social capital and value creation: The role of intrafirm networks. Acad. Manag. J. 1998, 41, 464-476.

50. Edelman, L.F.; Bresnen, M.; Newell, S.; Scarbrough, H.; Swann, J. The paradox of social capital: Structural, cognitive and relational dimensions. In Strategy in Transition; John Wiley \& Sons: Hoboken, NJ, USA, 2009; Volume 153.

51. Georgarakos, D.; Inderst, R. Financial Advice and Stock Market Participation. 2014. Available online: https: / / ssrn.com/abstract=1641302 (accessed on 5 June 2018).

52. Brown, J.R.; Ivkovich, Z.; Smith, P.A.; Weisbenner, S. The geography of Stock Market Participation: The Influence of Communities and Local Firms (No. w10235); National Bureau of Economic Research: Cambridge, MA, USA, 2004.

53. Doney, P.M.; Cannon, J.P. An examination of the nature of trust in buyer-seller relationships. J. Mark. 1997, 61, 35-51. [CrossRef]

54. Childers, T.L.; Rao, A.R. The influence of familial and peer-based reference groups on consumer decisions. J. Consum. Res. 1992, 19, 198-211. [CrossRef]

55. Kumar, A. Who gambles in the stock market? J. Financ. 2009, 64, 1889-1933. [CrossRef]

56. Rao, Y.; Mei, L.; Zhu, R. Happiness and Stock-Market Participation: Empirical Evidence from China. J. Happiness Stud. 2016, 17, 271-293. [CrossRef]

57. Liang, P.; Guo, S. Social interaction, Internet access and stock market participation-An empirical study in China. J. Comp. Econ. 2015, 43, 883-901. [CrossRef]

(C) 2018 by the authors. Licensee MDPI, Basel, Switzerland. This article is an open access article distributed under the terms and conditions of the Creative Commons Attribution (CC BY) license (http:/ / creativecommons.org/licenses/by/4.0/). 